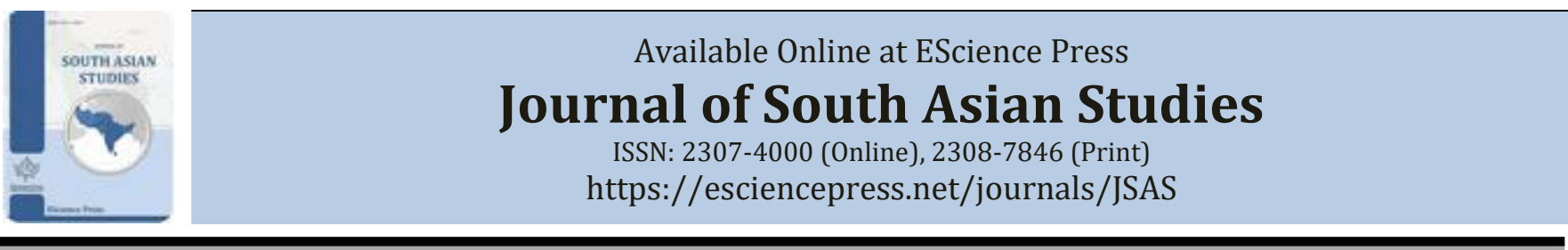

\title{
THE EMERGENCE AND DEVELOPMENT OF THE MUSLIM POLITICAL IDENTITY IN KASHMIR 1846-1947
}

\author{
Ghulam Q. Bhat * \\ Centre of Central Asian Studies, University of Kashmir, Srinagar-190006, Kashmir.
}

*Corresponding Author Email ID: b.qadir09@gmail.com

\begin{abstract}
A B S T R A C T
The century long Dogra rule in Kashmir was tyranted and undemocratic that provoked resentment among the Muslim subjects. During this rule, the socio-economic conditions of the Muslims became unsympathetic which finally led to the political consciousness among them. The Muslims in the state started organizing themselves to raise their demands for reforms in education, employment, the structure of taxation, and constitutional changes among various other things. Eventually, the state witnessed the politicization of the Muslim community in the form of a series of protest against the Dogra rule from 1930 to 1947. As a result, Kashmir during Dogra rule saw the emergence and development of the Muslim political identity. This paper attempts to trace the formation of the sense of political identity of the Muslim community and the emergence and role of the religio-political groups in sharpening the political identity of the Muslims in Kashmir. The present Kashmir crisis lies in the hundred years before when Kashmir was ruled by the succession of Hindu Dogra rulers.
\end{abstract}

Keywords: Muslim Identity, Politicization, Political Mobilization, Dogra Rule.

\section{INTRODUCTION}

The origin of the political identity of the Muslims in Kashmir goes back to1930s when mostly the Muslim subjects openly defied the Hindu Dogra rule. Under this rule, the Muslim population was as Prem Nath Bazaz puts it as '... a [Kashmiri] Muslim peasant presented the appearance rather of a starving beggar than one who filled the coffers of the state.' The significance of mass agitation in the political consciousness of the Muslims that erupted in Kashmir in connection with the alleged desecration of the holy Quran in 1931. The episode gave birth to the Muslim Conference, which was subsequently converted into National Conference. The base of this party was secularism, it tried to bring the people of all religions in its fold to struggle for democratic Kashmir.

The party was successful in its efforts of the secularization of political identity by channelizing the peasantry grievances into the radical demand of land to the tiller. This programme of land reforms were designed to consolidate the peasantry ties with India as Shaikh Abdullah had warned the peasantry that such type of reforms would not be possible in Pakistan. These reforms had a powerful impact on the political psyche of Kashmiris. Religious identity for them was not anymore, a serious issue, as people shifted their attention from religious to economic matters.

Shaikh Abdullah's adherence to secularism brought him closer to the Indian National Congress, whereas the Muslim of Jammu were influenced by the politics of the Muslim League. It is interesting to note that the conflict between the National Conference and the Muslim Conference was also a consequence of the difference in the attitude towards the events in British India. Though the two political groups were not directly involved in what was happening in British India, the National Conference supported the Congress's Quit India Movement, while the Muslim Conference backed Mohammed Ali Jinnah's call for a separate Muslim homeland. Thus, these two political groups became the part of larger politics of India and Pakistani nationalism in the post-partition era, where National Conference and Muslim Conference claimed accession of Kashmir into India and Pakistan respectively. The Indian claims were based on the fact that the Kashmiri identity was secular 
and thereby National Conference favored secular India. Pakistan, on the other side, claimed that it was a Muslim majority state and that the elements of its indigenous political elite, grouped around the Mirwaiz Moulvi Yousuf Shah under the banner of the Muslim Conference favored the Islamic Republic of Pakistan.

The objective of this paper is to examine the process of the formation of the political identity of Muslims and to see how this identity became the part of larger politics of India and Pakistani nationalism in the post-partition era.

\section{THE DOGRA RULE AND ITS IMPACTS}

The state of Jammu and Kashmir came under the Dogra rule by signing the treaty of Amritsar between the British and Maharaja Gulab Singh on 16 March 1846 (Lamb, 1991: 8). By selling Kashmir and bringing it under the subjugation of Gulab Singh, the British government did not even care to ascertain the wishes of the poor and helpless people of Kashmir (Thorp, 2011: 13). After purchasing the valley of Kashmir, Maharaja Gulab Singh declared that he was the sole owner of all lands, forests, mountains etc. in the valley (Thorp, 2011: 13).

The century-long Dogra rule in Kashmir was harsh and tyrant that provoked resentment among the Muslim subjects. The last Dogra ruler, Maharaja Hari Singh, continued to rule over Kashmir with an iron fist. Agriculture, for the majority of the population in rural areas, was the main source of livelihood and yet they did not have property rights to land (Sufi, 1949: 19). The revenue assessment of the Sikh period was continued by the Dogra rule under which the state took half share of the Kharif crop, i.e. four tracks per kharwar from Muslim peasants (Zutshi, 2003: 64). ${ }^{\mathrm{i}}$ Rabi crop was taken at the half share of the produce, i.e. three tracks per kharwar. In short, the cultivator had to pay more than half of the total produce to the state as tax. The cultivator had to feed the Darbar and the whole contingent of the revenue officials. The peasants thus ended up paying out of every 32 tracks of each Kharif crop, 21 tracks and 11 3/4 seers as revenue in kind; and out of 32 tracks of each Rabi crop, 20 tracks $63 / 4$ seers as revenue in kind (Zutshi, 2003: 65). Many landless laborers worked as serfs of these absentee landlords ${ }^{\mathrm{ii}}$ while others left the state and worked as laborers in neighboring Punjab (Sufi, 1949: 22).

Moreover, Kashmiri Muslims generally were not permitted to become military officers that was mainly led by Rajputs and Dogras and were also unrepresented in civil administration (Bose, 2003: 16). Right from the beginning Dogra rule over Jammu and Kashmir was harsh and oppressive. The policies adopted by them were markedly favorable to the Hindus (Copland, 1981: 234). Religious conversion legally banned was in favor of Hindu interest, the killing of cows was made capital punishment and goat killing was banned on a few specific days of the year. In Jammu, Azan (call to prayer) was sometimes prohibited. Moreover, newspapers were censored, and political parties were banned. Urdu newspapers, printed at Lahore and mostly read by the Muslims, were targeted by press censorship. A Bengali Christen, Sir Albion Banerjee, who was employed as Foreign and Political Minister in the State in 1929, declared that Kashmiri Muslims were treated like 'dump driven cattle' (Copland, 1981: 235). Therefore, it was in the backdrop of these adverse socio-economic conditions of the Muslim community that the political movement started against the Dogra rule during the 1930s.

The 1930s is considered as the era of popular politics in Kashmir. During this period two main events marked the historical importance of the political consciousness of Muslims. First, the formation of the Reading Room Party and second the Revolt of 1931. The educated Muslim youth after returning from the (British) Indian Universities, actively participated in the politics of the state. Prominent among them was the Sheikh Mohammad Abdullah, who had earned his degree at Aligarh Muslim University. Disappointed by the recruitment rules for civil services and finding only a few opportunities to accommodate their newly earned educational qualification, these men began to meet at Reading Room at Srinagar. They gradually coalesced into the Reading Room Party (Rai, 2004: 257). The party was mainly formed to demand adequate jobs for Muslims. It became a forerunner to the political movement and had the effect of early politicization of Kashmiri middle class Muslims. The feeling of hatred against the government was so strong that even the traditionally non- political figures, like Mirwaiz Yousuf Shah and Mirwaiz Hamdanithe two religious heads of Jamia Masjid and Khanqah-eMohalla, attended the meetings of this party. The Party worked in full cooperation with these two prominent religious figures who had used Mosques to organize meetings and protests against the Maharaja's government (Saraf, 2009: 361). Thus, the Reading Room Party and the institution of Mirwaiz, initiated a new 
political culture in the state.

\section{THE ROLE OF RELIGIOUS LEADERS}

At the beginning of the twentieth century, the evolution of the institution of Mirwaiz marked a new era in the religious history of Kashmir and played a new and dynamic role. Since the construction of Jamia (grand) Masjid in 1402, the institution established a single centre of religious authority (Chowdhary, 2008: 82). The institution began to address the issues of socio-economic backwardness of the Kashmiri Muslims. It was in 1901 that the Maharaja's government identified Rusul Shah as the single most useful figure capable of exercising a large influence over the Muslims of Srinagar. Moulvi Rusul Shah founded the Anjuman-i-Nasratul Islam in 1899- a socio-religious movement aimed at reforming the society by eradicating the social evils and popularizing the education among the Muslims. His successor Moulvi Yousuf Shah extended his support to the movement against the Dogra rule. During the decade of 1930, the institution of Mirwaiz became powerful enough to confront Maharaja's administration for not providing more opportunities for Kashmiri Muslims in education, administrative posts and relaxation of taxation for the peasants. Moreover, the Mirwaiz played a pivotal role in setting-up the Muslim Conference, the first political party.

There had been two Mirwaizesiii in the valley- the Mirwaiz Hamdani and the Mirwaiz Kashmir, the former preached at Khanqah-i-Maulla (Shah-i-Hamdan) and the later at Jamia Masjid (Zutshi, 2003: 130). There were differences between the two Mirwaizes on religious beliefs as also on the control of the Mosques and Shrines. Mirwaiz Yousuf Shah of Jamia Masjid was against shrine culture and his followers were called Kota (fundamentalists). While Mirwaiz Hamdani of Khanqahe-Mohalla, approved shrine culture and his followers were called Cheta (tiger) (Rai, 2004: 232). Each lineage is traditionally the preserver of a single family that traces its roots to Sufi saints who came to the Kashmir Valley from Central Asia.

The revolt of 13 July 1931 marked the beginning of the 'freedom struggle' waged by Kashmiris against the Dogra rule. It was the first time that the Muslims of Kashmir openly challenged the government of Maharaja (Rai, 2004: 258). The spark of the revolt was lit by Fazldad, the constable of the Jammu Central jail when he complained against the Hindu head constable Lamba Ram of desecrating the Holy Quran (Saraf, 2009: 363).
The sense of grief and anger among the Muslims reached its nadir when they found the pages of Quran in the drain. The situation became worse by the arrest of Abdul Qadir, a Punjabi Muslim who had delivered an inflammatory speech during the meeting of Kashmiri Muslims held at the shrine of Shah-i-Hamadan. He was arrested on charges of sedition and the date of his trial was set for 13 July 1931, at Srinagar Central Jail. The demonstrators, gathered outside the Central Jail to witness the trial of Abdul Qadir, raised slogans demanding the withdrawal of the case against the accused Qadir and rushed towards the gate. The scuffle broke out between the police and the demonstrators in which 21 people died. As the dead bodies were being carried towards the Jamia Masjid, their wrath turned against the Hindus in which three Hindus lost their life. Shops belonging to the Hindu community were also looted at Maharj Gunj, then financial capital of Srinagar (Bamzai, 2007: 133).

Though the revolt of 1931 was perceived communal in nature, the actual cause of the demonstration was the anger and frustration of the Muslim community's poor socio-economic and political status. Despite their attacks on the Hindu Community, the main target of revolt was the state. Giyas-ud-din, in his book Understanding the Kashmir Insurgency, writes that the revolt of 1931, was an authentic revolt launched by the people against the socio-economic and political oppression by the ruling class. The rebellious elements, according to him were the trading class, Muslim intelligentsia and the peasantry class who were moaning under the feudal rule (GayasUd-Din, 1997: 83). One of the protagonists described it as 'a war of the oppressed against the oppression.' Its aim was nothing more than to seek justice and redressal (Chandra, 1985: 40). Thus, the involvement of Reading Room Party in addressing the problems of Muslims, the revolt of 13 July 1931 and the role played by the Muslims from Punjab brought the various religious and political parties together which resulted in the formation of Muslim Conference.

\section{MUSLIM CONFERENCE}

The first political party: The Muslims of Punjab played an important role in awakening the Muslim consciousness and forming the first political party Muslim Conference (MC) in 1932. The involvement of Muslims from Punjab in voicing the atrocities of Muslims in Kashmir was tremendous. Historically, Kashmir has always been a sensitive issue among the Muslims of 
Punjab, due to the influence of Kashmiri Baradari (brotherhood) (Samad, 1995: 77). It was during early $20^{\text {th }}$ century that famine and unfavorable policies of Dogra rulers led to mass migration of Kashmiri Muslims to Punjab and got settled there (Sevea, 2012: 16). These people of Kashmiri origin along with other Punjabi Muslims campaigned in support of Kashmiri Muslims (Samad, 1995, 77). Dr Sir Muhammad Iqbal, one among the prominent personalities, was actively involved in organizations such as Anjuman Kashmiri Musalman (society of Kashmiri Muslims). He later formed the All India Kashmir Committee and became a staunch supporter of the Muslim protests in Kashmir against the Dogra rule. He took an active part in galvanizing the Muslims to overcome sectarian differences and to rise against the Dogra rulers (Sevea, 2012: 17). It was the result of politicization of the Kashmiri Muslim identity that the first organized political response could be seen in the form of MC (Chowdhary, 1998: 11).

Shaikh Abdullah from the Valley of Kashmir and Chowdary Ghulam Abbas from the Jammu region were the principal leaders of MC (Saraf, 2009: 482). MC demanded greater share for educated Muslims in the civil service, better working conditions and recruitment of the Muslims into army, there were also issues related to land ownership, and lower land revenue to be charged to the peasantry. Religious demands included the return of Mosques to the Muslim community and the removal of the impediments to the conversion of Hindus to Islam (Behra, 2006: 16). The party enjoyed the support of all the major Muslim groups, such as young graduates of formerly Reading Room Party, the Jammu Young Man's Association, Mirwaiz Kashmir, Yusuf Shah, Mirwaiz of Khanqah-e-Moalla, Hamdani and the small but politically active Qadani community (Saraf, 2009: 482). Subsequently, the internal differences within MC developed into two rival factions; one faction was led by Shaikh Abdullah and supported by Maiwaiz Hamdani and the other faction was headedby Mirwaiz Yousuf Shah of Jamia Masjid. MC also faced stiff opposition from the Kashmiri Pandits, who perceived their demands against the political and economic interests of their community (Rai, 2004: 267-269).

\section{DEMAND FOR POLITICAL RIGHTS OPPOSED BY PANDIT'S}

The Dogri speaking Hindus or Dogras in Jammu and the Kashmiri speaking Panditsiv or Hindus in the Valley had a dominant position vis-a-vis Muslims in education, civil administration and were the owners of big Lands. When Muslims began to agitate for better education and employment, non-Muslims perceived its threat to their vested interests and domination. So, any concession made to the Muslims by Maharaja was opposed by the non-Muslims. It was under the orders of Maharaja that the Glancy commission'was appointed in 1931. The commission submitted its report on 22 March 1932, which recommended an increased share for Muslims in the state services. This was perceived against the dominant position of the Hindus; they strongly opposed it (Zutshi, 2003: 237).

An earlier threat to the administrative dominance of Pandit community came around the last decade of 19th century when a large number of Punjabis were imported by the Dogra state to man them in higher administrative positions. The turning point for the Kashmiri Pandits came around 1889 when the newly established State Council changed the court language from Persian to Urdu, and the rules were framed to hold competitive exams for the appointment to the government services (Rai, 2004: 243). Having invested centuries in their literacy in Persian in order to maintain their hold on power through state employment, this community suddenly found the rug pulled from under their feet. The cumulative effect of these measures was that Kashmiri Pandits were increasingly put out of these prestigious ranks of the administration (Rai, 2004: 244). The organizations like Sanatan Dharma Young Men's Association, also known as Yuvak Sabha founded by members of the Kashmiri Pandit community in 1893, worked to protect jobs from Muslim encroachment. The Sanatan Dharma Young Men's Association even made a written representation to the then Prime Ministerof Maharaja that recommendations of the Glancy Commission and the limited implementation of them caused the Pandits to accuse the government of being pro-Muslim. Thus, the Pandits privileges were decidedly shaken with the Muslim demands for special concessions in education to overcome their backwardness and for an equal share in the state services in proportion to their population (Rai, 2004: 248). As a result, the two communities began to compete with each other while making their demands to Maharaja and were often manifested into communal hatred. Therefore, the leaders of MC secularized the party for the inclusion of Kashmiri Pandits in their struggle. 


\section{THE SECULARIZATION OF MUSLIM IDENTITY THROUGH INCLUSIVE POLICIES}

The politicization of Muslim identity alone could not define the political situation of Kashmir for long. The members of MC felt discomfort in context of sharpening communal tension, which had the impact of shaking the roots of harmony between Muslims and Hindus in the state (Bamzai, 2008: 658). Shaikh Abdullah believed that restrictive nature of $\mathrm{MC}$ and the communal nature of politics had a limiting effect on the purpose of a political movement. As a result, Shaikh Abdullah along with Prem Nath Bazaz started an Urdu newspaper 'Hamdard' in 1935, to extend the ideological base and support of the movement (Rai, 2004: 275). While addressing the MC in March 1938, Shaikh Abdullah said:

We desire that we should be free to set our house in order and no foreign or internal autocratic power should interfere in our national and human birthrights. This very demand is known as Responsible Government... The first condition to achieve Responsible Government is the participation of all those people... They are not the Muslims alone nor the Hindus and Sikhs alone, nor the untouchables and Buddhists alone, but all those who live in this state alone... We do not demand Responsible Government for 80 lakh Muslims but all the 100\% state subjects (Behra, 2006: 17).

A special session was convened on 11 June 1939, in which MC was renamed as National Conference (NC) vi the bearer of the people's nationalist ideology. Shaikh Abdullah in his autobiography Aatish-i-Chinar described the class base of $\mathrm{NC}$ as:

Our movement had been thrown open to all religious groups. It became imperative to develop new political and economic rallying points. We had learnt from experience that the real reason for conflict was not religion but a clash of interests between different classes and groups. The primary objective of our movement was to oppose oppression and support the oppressed (Abdullah, 1993: 534).

Kashmir, therefore, witnessed the process of the formation of political identity which transcended its narrow religious limitations. The party was successful in its efforts of secularization of the political identity by channelizing peasantry grievances into land to the tiller (Bazaz, 1954: 68). Prem Nath Bazaz, a Kashmiri Pandit, rejoiced at the trend towards secularism writes:
The freedom movement had come out of the mire of communalism and was shining in all its brilliance in the high pedestal of nationalism . . many Kashmiri pandits fought shoulder to shoulder with Muslims and suffered equally with them in their struggle against unemployment, high taxes, revenue demands and lack of medical facilities (Bazaz, 1954: 68).

Apart from the attempt of bringing different strata of society under common platform, the other factors responsible for changing the name of $\mathrm{MC}$ into $\mathrm{NC}$ is said to be the close affinity of Shaikh Abdullah with Indian National Congress (INC), particularly with Jawaharlal Nehru. Kashmir being the ancestral homeland of Nehru, he took special interest and was able to convince Abdullah that the movement against Dogra rule should not be confined to the Muslims alone, but should include non- Muslims as well (Hussain, 2005: 112).

Despite the personal links of Abdullah and Nehru and the ideological affinity of the $\mathrm{NC}$ with certain sections of the INC, the NC maintained its distinct identity from that of the Congress Party. The two important characteristics that distinguished the NC from the Congress in British India was: Firstly, it retained its ideology of regional patriotism, centered on Kashmir and secondly, the NC never abandoned its Kashmiri Muslim heritage, despite its declaration of secularism and inclusion of nonMuslims. It is noteworthy to mention here that NC which claimed to provide secular platform for communities across faith, had its ideology and mobilization strategies steeped in a distinctly Muslim ethos shaped above all by the Valley's history, culture and traditions (Bose, 2003: 24). In short, the secularism practiced by the NC did not abandon religious practices while leading a movement for political rights. Instead, it gave emphasis more on religious tolerance.

While on the other side, the political responses of the Muslims in Jammu were different as they were highly influenced by the Muslim League. That is why the Muslims of Jammu region were against the secularization of Kashmir politics and could not continue their affiliation with it (Chowdhary, 2008: 16). Several prominent leaders including Chowdhary Ghulam Abbas were critical of NC, for being close to the Indian National Congress. They believed that the Hindu-Sikh elements in the Congress, leading India's independence movement, would be detrimental to the Kashmiris freedom movement because of their vested interests in the Dogra rule. Moreover, the vast majority of Hindus remained 
skeptical about Shaikh Abdullah's nationalist claims. Notwithstanding, Sheikh Abdullah's non-communal class politics, they felt that his party was predominantly Muslim and thus feared the community's overwhelming domination (Malik, 2005: 87). In sum, the NC could not succeed in bringing everyone in its fold of secular politics.

\section{THE TUSSLE BETWEEN SECULAR AND RELIGIOUS IDENTITY OF KASHMIRIS}

Some Muslim members of NC, disillusioned with Shaikh's secularism and his close friendship with Nehru, revived the former Muslim Conference in 1941. Choudary Ghulam Abbbas, the president of MC and Mirwaiz Yosuf Shah, a religious preacher had been Abdullah's arch-rival since the 1930s. The rivalry between these two groups continued for a space in Kashmir politics and defined the nature of the movement against the Dogra rule. MC, which gave more importance to the Muslim identity of Kashmiris failed to win the hearts and minds of the Valley Muslims (Saraf, 2009: 490). Likewise, the NC under the leadership of Abdullah also failed to extend its base in Jammu. Attempts made to unite the $\mathrm{NC}$ and the $\mathrm{MC}$ into a single party failed. There were several reasons including the fact that NC did not represent Jammu Muslims very effectively, and pro-Congress orientation of the organization made many of its members uncomfortable. Therefore, both the parties clashed which often became violent.

Shaikh Abdullah's adherence to secularism brought him closer to the Indian National Congress, whereas the Muslim s of Jammu were influenced by the politics of Muslim Congress. It is interesting to note that the conflict between $\mathrm{NC}$ and the MC was also a consequence of the difference in the attitude towards the events in British India. Though the two political groups were not directly involved in what was happening in British India, the NC actively supported the Congress' Quit India Movement, while the MC backed Mohammed Ali Jinnah's call for a separate Muslim homeland. In turn, the Indian National Congress recognized the $\mathrm{NC}$ as the real representative of Kashmiris. In 1946, following the Quit India Movement, Abdullah called for a Quit Kashmir movement against Maharaja Hari Singh in the state. Consequently, Shaikh Abdullah and other leaders of NC were arrested. Shaikh's political opponents criticized him by saying he had begun the agitation to boost his popularity which was being threatened by his pro-
Congress stance (Saraf, 2009: 103). Ghulam Abbas, on the other hand, was also arrested when he started a similar campaign which was based on Jinnah's direct action against British India Government (Taher, 2009: 371). The MC's strategy was to rely more on the cooperation of Maharaja and on 21 May 1947 appealed him to declare Kashmir as an independent state. Chowdhury Hamidullah, then acting President of the MC, promised Maharaja that the Muslims would readily acclaim him as the first constitutional King of a democratic and independent Kashmir.

The tussle between these two political groups became the part of larger politics of India and Pakistani nationalism in the post-partition era, where NC and MC claimed accession of Kashmir into India and Pakistan respectively. The Indian claims were based on the fact that the Kashmiri identity was secular and thereby the NC favored secular India. Pakistan, on the other side, claimed that Kashmir being a Muslim majority state and that the elements of its indigenous political elite, grouped around the Mirwaiz Moulvi Yousef Shah under the banner of the MC, favored the Islamic Republic of Pakistan.

\section{JINNAH-ABDULLAH CONFLICT}

On 10 May 1944 on the invitation of Shaikh Abdullah, Mohammad Ali Jinnah visited Jammu and Kashmir. While addressing a reception meeting of the NC at Srinagar, which Jinnah himself described as the "royal welcome" he said:

This reception is not meant for my person; it is meant for the All-India Muslim League of which I am the president. By it you have honoured the Muslims of India who are organized under the Muslim League (Gupta, 1966: 58).

On 17 June 1944 Jinnah while addressing the

Muslim Conference, he said:

As a Muslim, I must say what I feel is the right way for the Muslims. So far as I have been able to understand the viewpoint of the leaders of the National Conference, I do not think they can succeed...with one objective in view, you should establish one platform and one organization and rally round one banner.... 99 percent of the Muslims who met me are the opinion that Muslim Conference alone is the representative organization of the state Muslims (Gupta, 1966: 58).

Though Shaikh Abdullah and his party held grand reception in Jinnah's honour, he came in sharp conflict 
with the Jinnah, whose speech did not go well with the NC and its followers. He further said:

Muslims have one platform, one Kalma and one God.

I would suggest the Muslims to come under the banner of MC and fight for their rights.

Sheikh Abdullah in reply said:

The ills of this land can only be remedied by carrying Hindus, Muslims and Sikh's together (Panigrahi, 2009: 23).

To put it in a nutshell, Jinnah's statement became the turning point for shaping the future status of Kashmir.

The close association of MC with the Muslim League had led to the transformation of the former from that of an organization which had registered dissent against the $\mathrm{NC}$ to an organization that presented a viable alternative to the NC. As noted by Gulam Abbas 'we have stolen a long march on our opponents since the Quaidi-i-Azim's visit' (Zutshi, 2003: 288-289). The NC had to take drastic steps to regain its influence among the Kashmiris which was declining fast. Thus, NC under the leadership of Shaikh Abdullah adopted a plan which came be known as the Naya (new) Kashmir or Naya Kashmir Manifesto (Zutshi, 2003: 289). This programme of land reforms were designed to consolidate the peasantry's ties with India (Schofield, 2000: 77). Economic reforms, according to Josef Korbal, were introduced to counter the demand of plebiscite made by Pakistan:

For the party which has the more serious reasons to be fearful of the result of plebiscite - the government in Srinagar - has been doing everything in its power to delay this of reckoning. It has been working hard to change the conditions of life under the Maharaja and to bring some relief to the poverty stricken masses.

On January 11, 1948 People's Age in its editorial wrote:

The game of Pakistani reactionaries and of the imperialist war mongers can be easily defeated if the peasant masses of Kashmir are assured that feudal autocracy and jagirdari will be liquidated, land will be given to the tillers, and the complete right of selfdetermination granted to the various nationalities that comprise Kashmir. Kashmir can be saved only by winning over the peasants and ending feudal autocracy and the reactionary policy of the appeasement of the Maharaja by the Union government and by really liberating peasants (Prasad, 2014: 132).
Land was one of the basic issues for masses, the politics of reforms changed the mind of the people. Religious identity of the farmers looked no more any serious issue, as large segments of the population shifted their attention from religious to economic matters (Walinsky, 1977: 188-189). The Naya Kashmir plan advocated the socialization of all production and the reorganization of property relationships. According to this plan, land does not belong to a landlord, but a tiller and the former has no right over the later or his land. Contrary to Pakistan, the prospects for such a land reformation loomed large within Indian political framework. Thus, the belief of the peasantry found refuge in the personality and the political programme of Shaikh Abdullah (Ganguly, 2001: 16).

If the difference between Jinnah and Abdullah could have been bridged, that would have benefited the people of Kashmir, the leaders like Mirwaiz Yousuf Shah and Ghulam Abas had made it clear that there was no way to create a union of theNC and MC. As a result, MC moved away further and became subservient to the Muslim League and the $\mathrm{NC}$ came closer to the Congress (Choudary, 2013: 58).

Meanwhile, armed rebellion broke out in Poonch, in protest against the Maharaj's rule on October 1947, changed the political scenario in the State. Maharaja of Jammu and Kashmir was reluctant in his decision to join either of the two newly born countries of India and Pakistan. His interests, he felt would be satisfied by remaining independent. R.B Batra, the then deputy Prime Minister, in a press statement made it clear by saying that:

We intend to keep friendly relations with both Pakistan and the Indian Union. Despite constant rumours we have no intention of joining either India and Pakistan ... the Maharaja has told me that his ambition is to make Kashmir the Switzerland of the East- a state that is completely neutral (Guha, 2017: 774).

The agitation started by the poor Muslim peasants in Poonch district, took the form of armed uprising in the spring of 1947. The London Times reported on 10 October that the Muslims in Poonch were "systematically exterminated" by the forces of Hindu Maharaja of Kashmir. Many of these Muslims fled to Pakistan, who sympathetically listened to their brethren about the tales of Hindu terror. They were supported and armed by the Pakistanis, and later joined by Frontier 
Pathan Tribals (Wolport, 2006: 183). To combat the situation Shaikh Abdullah, who had earlier imprisoned by Maharaja in 1946, was released. However, Shaikh Abdullah's realize was termed as conspiracy by Pakistan and her supporters, as the leaders of MC who were also jailed were not released (Schofield, 1996: 24). As Shaikh Abdullah was against the Maharaja's government, after releasing him, he addressed the situation in his own way. He vehemently demanded the demise of Dogra rule and the accession of Jammu and Kashmir State either India or Pakistan as per the wishes of the people of Kashmir irrespective of their religion. On 5 October 1947, at a special meeting in Srinagar Sheikh Abdullah declared:

Our first demand is the complete transfer of power to the people. Representatives of the people in a democratic Kashmir will then decide whether the State should join India or Pakistan. If the forty lakhs of people of [the State] are by-passed and the State declares its accession to India or Pakistan, I shall raise a banner of revolt... We will naturally opt to go to that dominion where our own demand for freedom receives recognition and support. . . (Korbel, 1955: 69).

As Maharaja's forces were not able to resist the tribal attack, he urgently appealed to the Indian government. Lord Mountbatten, before dispatching his forces to Kashmir, asked for legal formalities had to be completed regarding accession (Campbel, 1972: 224). It transpired that this help was only to be forthcoming on two or three conditions. One, Maharaja Signs the instrument of accession, Second Shaikh Abdullah be sworn as states Prime Minister, third condition was put forth by the Governor General of India Lord Mountbatten who pointed out that this accession would be temporary till it is referred to the people in Kashmir. In his words:

Where the issue of accession has been the subject of the dispute, the question of accession should be decided in accordance with the wishes of the people of the State. It is my governments wish that as soon as law and order have been restored in Kashmir and her soil cleared of the invaders, the question of the state's accession should be settled by a reference to the people (Letter, 1947).

It was in the backdrop of these circumstances that the instrument of accession was signed on 26 October 1947, by Maharaja Hari Singh to India. Shaikh Abdullah the popular leader during that period supported the Accession in the belief that it was not completely binding. Since it was to be ratified by a plebiscite once peaceful conditions restored. But Maharaja's accession did not end the uncertainty over Kashmir's status for three basic reasons: First, the accession was to be referred to the people of Jammu and Kashmir, second, the Kashmir problem was moved to the United Nations Security Council (UNSC) for a peaceful resolution, and third the state had to be cleared by the invaders (Puri, 1993: 15).

\section{CONCLUSION}

The above analysis has shown that Dogra rule over Jammu and Kashmir was tyrant and undemocratic that provoked resentment among the Muslim subjects. The socio-economic conditions of the Muslims became unsympathetic which finally led to the political consciousness among them. To overcome their socioeconomic backwardness the Muslims in the state started organizing themselves to raise their demands for reforms in education, employment, structure of taxation, and constitutional changes among various other things. Therefore, it was in the backdrop of these adverse socioeconomic conditions of the Muslim community that the political movement started against the Dogra rule during 1930s. It was the result of politicization of the Kashmiri Muslim identity that the first organized political response could be seen in the form of MC. However, the conversion of Muslim Conference into National Conference could not succeed in bringing everyone in its fold of secular politics. Some Muslim members of NC revived the former Muslim Conference in 1941.Shaikh Abdullah's adherence to secularism brought him closer to the Indian National Congress, whereas the Muslims of Jammu were influenced by the politics of Muslim League. Though, the two political groups were not directly involved in what was happening in British India, the NC actively supported the Congress' Quit India Movement, while the MC backed Mohammed Ali Jinnah's call for a separate Muslim homeland. As a result, it became the part of the larger politics of Indian and Pakistani nationalism in the post-partition era. Both the leaderships of India and Pakistan, therefore, claimed Kashmir's accession to their respective countries. Indian claims were based on the fact that the Kashmiri identity was secular and thereby the NC favored secular India. Whereas Pakistan claimed Jammu and Kashmir was the Muslim Majority state and that the elements of its indigenous political elite, grouped around the Mirwaiz Moulvi Yousef Shah under the banner of the MC, favored 
Islamic Republic of Pakistan. Thus, the genesis of the present Kashmir crises lies in the hundred years before the creation of India and Pakistan, when Kashmir was ruled by the succession of Hindu Dogra rulers.

\section{REFERENCES}

Abdulla, S.M. (1993). The Flames of Chinar: An Autobiography. New Delhi: Viking.

Bamzai, P.N. (1954). The History of Freedom Struggle in Kashmir: Cultural and Political. New Delhi: Kashmir Publishing Company.

Bamzai, P. N. K. (2007). The Culture and Political History of Kashmir, Vol.3. Srinagar: Gulshan Books.

Bamzai, N.K. (2008). A History of Kashmir: Political, Social and Cultural: From the Earliest to the Present Day. Srinagar: Gulshan Publishers.

Behra, C.N. (2006). Demystifying Kashmir. Washington D.C: The Brooking Institution Press.

Bose, S. (2003). Kashmir Roots of Conflict, Paths to Peace. New Delhi: Vistar.

Campbell, J. Alan. (1972). Mission with Mountbatten. New York: E. P. Dutton \& co.

Chandra, P. (1985, June). The National Question in Kashmir. Social Scientist, 13 (6), 40.

Choudary, S. (2013). Tribal Invasion and Kashmir: Pakistan Attempts to Capture Kashmir in 1947, Division of Kashmir and Terrorism. UK: Author House.

Chowdhary, R. (1998). The Muslim Identity and the Politics of Fundamentalism in Kashmir. Queen Elizabeth House Working Paper Series (QEHPS), (October): 16.

Chowdhary, R. (2008). Religion and Discourse of Identity in Kashmir. In Brar. B, Kumar. A \& Ram. R (Eds), Globalization and Politics of Identity in Kashmir. New Delhi: Pearson Education.

Copland, I. (1981). Islam and Political Mobilization in Kashmir 19331-34. Pacific Affairs, 54(2), 233-234.

Ganguly, S. (2001). Conflict Unending: India-Pakistan Tensions since 1947. New York: Oxford University Press.

Gayas, U.D. (1997). Kashmir: Islam, Ideology and Society. In Puri, B (Eds), 5000 Years of Kashmir. Delhi: Ajanta.

Guha, R. (2017). India After Gandhi: The History of the World's largest Democracy. Picador.

Gupta, S. (1966). Kashmir: A Study in India-Pakistan Relations. New Delhi: Asian Publishing House.

Hussain, R. (2005). Pakistan's relations with Azad
Kashmir and the Impact on Indo-Pakistani Relations. In Dossani, R \& Rowen, H.S (Eds), Prospects for Peace in South Asia. California: Stanford University Press.

Korbel, J. (1955). Danger in Kashmir. Princeton N.J: Princeton University Press.

Lamb, A. (1991). Kashmir: A Disputed legacy 1846-1990. Karachi: Oxford University Press.

Letter of Mountbatten to Maharaja Hari Singh, Dated, October27, 1947; I.O.L.R, L/P \& S/13/1854B, 497498.

Malik, I. (2005). Kashmir: Ethnic Conflict International Dispute. Oxford: Oxford University Press

Panigrahi, D. N. (2009). Jammu and Kashmir: The Cold War and the West. New Delhi: Routledge.

Prasad, A.K. (2014). Shaikh Abdullah and Land Reforms in Jammu and Kashmir. Economic and Political Weekly, 49(31), 132.

Puri, B. (1993). Kashmir: Insurgency and After. New Delhi: Orient Longman Private Limited.

Rai, M. (2004). Hindu Rulers Muslim Subjects: Islam, Rights and the History of Kashmir. New Delhi: Permant Black.

Saraf, M. Y. (2009). Kashmiris Fight for freedom 18191946. Lahore: Feroz Sons.

Samad, Y. (1995). Kashmir and the Imagining of Kashmir. Contemporary South Asia, 4 (1), 66-77.

Sevea, I.S. (20120. The Political Philosophy of Mohmmad Iqbal: Islam and National in the Late Colonial Inida. New York: Cambridge University Press.

Schofield, V. (1996). Kashmir in the Crossfire. London New York: I. B Tauris.

Schofield, V. (2000). Kashmir in Conflict: India, Pakistan and the Unending War. London New York: I.B Tauris Publishers.

Sufi, G.M.D. (1949). Kashmir: Being a History of Kashmir from the Earliest to Our Own, Vol. 11. Lahore: University of Punjab.

Thorp, R. (20011). Kashmir Misgovernment. Srinagar: Gulshan Books

Taher, A.S. (2009). The Early-1990 Kashmiri Muslims Uprising's Endogenous Basis: Exploring the Ethno-Cultural Roots. BIISS, 30(4), 371.

Walinsky. Louis, J. (ed), (1977). Agrarian Reforms as Unfinished Business, the selected papers of Wolf Ladejinsky (English). Unnumbered series; no. UNN 188.. New York, NY: Oxford University Press. http://documents.worldbank.org/curated/en/76 
1501468765882964/Agrarian-reform-as-

unfinished-business-the-selected-papers-of-Wolf-

Ladejinsky
Wolport, S. (2006). The last Years of the British Empire in India. Oxford University Press.

\section{Notes}

${ }^{\mathrm{i}}$ The government scale weights used in collecting their proportion of grain was: 6 seers $=1$ trak, 16 traks $=1$ kharwar, while in selling the grain to the people the scale was changed as following: 6 seers $=1$ trak, 15 traks $=1$ kharwar. For further details See Chitralekha Zutshi, Languages of Belonging: Islam Regional Identity and Making of Kashmir (Delhi: Permanent Black, 2003), p.64.

ii During the British rule, the agriculture policy of the state was so adopted that it deprived the actual cultivators of their rights in land and developed and strengthen the position of the landowners, who did not cultivate the lands with their own hands.

iii During the early $20^{\text {th }}$ century the two Mirwaizes hailed from the same family split into two groups, as the two brothers competed for the position as head preacher at Jamia Masjid. One of the brothers moved his sphere of influence to Khanqah-i-Mualla, while the other stayed on at Jamia Masjid as the head preacher of the city. The descendents of the former identified themselves as Mirwaiz Hamdaani and those of the latter retained their position as Mirwaiz Kashmir of Jamia Masjid. See Zutshi, Languages of Belonging, p.130.

iv The native Hindus of Kashmir belong to the Brahman Varna. They call themselves Bhatta and in India are generally known as Kashmiri Pandits.

${ }^{v}$ Galancy Commission was appointed on 12 November 1931, by the Maharaja Bahadur, under the chairmanship of Sir B. J. Glancy, to enquire into Grievances and Complaints of Muslims of the state.

vi The split of All Jammu and Kashmir Muslim Conference in 1939 resulted in the emergence of National Conference of National Conference.

Publisher's note: EScience Press remains neutral with regard to jurisdictional claims in published maps and institutional affiliations.

Open Access This article is licensed under a Creative Commons Attribution 4.0 International License, which permits use, sharing, adaptation, distribution and reproduction in any medium or format, as long as you give appropriate credit to the original author(s) and the source, provide a link to the Creative Commons license and indicate if changes were made. The images or other third-party material in this article are included in the article's Creative Commons license, unless indicated otherwise in a credit line to the material. If material is not included in the article's Creative Commons license and your intended use is not permitted by statutory regulation or exceeds the permitted use, you will need to obtain permission directly from the copyright holder. To view a copy of this license, visit http://creativecommons.org/licenses/by/4.0/.

(C) The Author(s) 2019. 